\title{
First report of the Brahminy Blindsnake, Indotyphlops braminus (Daudin), from the Caribbean island of Montserrat
}

\author{
Sarah J. Snyder ${ }^{1}$, Robert E. Schmidt ${ }^{1 *}$, and Nicolas Tirard ${ }^{2}$ \\ 'Bard College at Simon's Rock, 84 Alford Rd., Great Barrington, MA 01230, USA. \\ ${ }^{2}$ Montserrat National Trust, Little Bay, Montserrat. \\ *Corresponding author (schmidt@simons-rock.edu)
}

Date of publication: 12 March 2019.

Citation: Snyder SJ, Schmidt RE, Tirard N (2019) First report of the Brahminy Blindsnake, Indotyphlops braminus (Daudin), from the Caribbean island of Montserrat. Caribbean Herpetology, 65, 1-2.

DOI: $10.31611 /$ ch.65

The herpetofauna of Montserrat includes only two snakes, Alsophis manselli and Antillotyphlops monastus, both endemic (Hedges et al. 2009; 2014). Therefore, the discovery of an introduced third species is important, especially when it may pose a threat to the native blindsnake, Antillotyphlops. Here, we report the presence of Indotyphlops braminus, the Brahminy Blindsnake, on Montserrat. One individual, $130 \mathrm{~mm}$ in total length, was collected under a rock in the Belham River Valley, Salem (16.74139, -62.21861) in late April 2017 by N. Tirard. It was preserved in ethanol and catalogued into the collection of the New York State Museum (NYSM 6453). This is the first record of that invasive species from Montserrat but it has been documented from other Caribbean Islands: Anguilla, Barbados, Grand Cayman, Grand Turk, Guadeloupe, La Désirade, Martinique, New Providence, Petite St. Vincent, Providenciales, St. Barthélemy, St. Croix, St. Eustatius, St. Kitts, and St. Martin (Powell \& Henderson 2012, Lorvelec et al. 2016).

Indotyphlops braminus is a triploid obligate parthenogen (Wynn et al. 1987) with a clutch size of 1-8 (Ota et al. 1991). The clutch size of Antillotyphlops monastus is unknown but is probably similar. Given that half of the $A$. monastus population are females and all I. braminus are females, if all else is equal, $I$. braminus will produce more offspring than A. monastus. Blindsnakes generally eat ants and termites (Webb et al. 2001) and therefore the two blindsnakes on Montserrat are probably competing for food. Powell et al. (2016) listed the Montserrat blindsnake as "near threatened." The presence of a competitor that probably reproduces more quickly may further threaten this endemic blindsnake population.

For field identification, Indotyphlops braminus usually is very dark dorsally, sometimes appearing black. The Montserrat blindsnake is paler dorsally, often pinkish-tan in coloration. Under magnification, Indotyphlops (Fig 1A) differs in head scalation (Hedges et al. 2014) from Antillotyphlops (Fig. 1B).
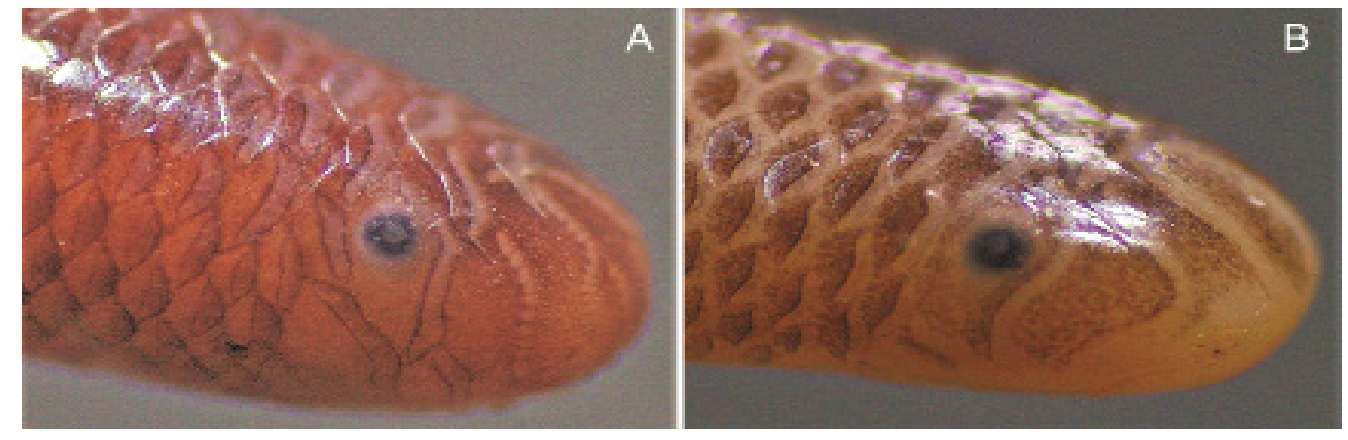

Figure 1. Lateral view of head of (A) Indotyphlops braminus (NYSM 6453) and (B) Antillotyphlops monastus (NYSM 6454). 


\section{Acknowledgments}

Specimens were collected under a Memorandum of Understanding between Bard College at Simon's Rock and the Government of Montserrat. We appreciate the continued support of E. Corbett and S. Mendes, Montserrat Ministry of the Environment. We thank S.B. Hedges and A. Wynn for commenting on the manuscript.

\section{References}

Hedges SB, Couloux A, Vidal N (2009) Molecular phylogeny, classification, and biogeography of West Indian racer snakes of the tribe Alsophiini (Squamata, Dipsadidae, Xenodontinae). Zootaxa, 2067, 1-28.

Hedges SB, Marion AB, Lipp KM, Marin J, Vidal N (2014) A taxonomic framework for typhlopid snakes from the Caribbean and other regions (Reptilia, Squamata). Caribbean Herpetology, 49, 1-61.

Lorvelec O, Berchel J, Barré N (2016) First report of the Flowerpot Blindsnake, Indotyphlops braminus (Daudin, 1803), from La Désirade (Guadeloupe Archipelago, the French West Indies). Caribbean Herpetology, 55, 1-2.

Ota H, Hikida T, Matsui M, Mori A, Wynn A (1991) Morphological variation, karyotype and reproduction of the parthenogenetic blind snake, Rhamphotyphlops braminus, from the insular region of East Asia and Saipan. Amphibia-Reptilia, 12, 181-193.

Powell R, Daltry JC, Dewynter M (2016) Typhlops monastus (errata version published in 2017). The IUCN Red List of Threatened Species 2016: e.T75607344A115492884. Available online at http://dx.doi.org/10.2305/IUCN. UK.2016-3.RLTS.T75607344A75608199.en. Accessed 2 March 2018.

Powell R, Henderson RW, eds (2012) Island lists of West Indian amphibians and reptiles. Bulletin of the Florida Museum of Natural History, 51, 85-166.

Webb JK, Branch WR, Shine R (2001) Dietary habits and reproductive biology of typhlopid snakes from southern Africa. Journal of Herpetology, 35, 558-567.

Wynn A, Cole CJ, Gardner AL (1987) Apparent triploidy in the unisexual Brahminy blind snake, Ramphotyphlops braminus. American Museum Novitates, 2868, 1-7. 